\title{
Przez język ukrycia po słowo na ,g". Kim są bohaterowie czasów queer before gay?
}

Aвstract: Nowak Tomasz Łukasz, Przez język ukrycia po słowo na „g”. Kim sa bohaterowie czasów queer before gay? (Language of Concealment and the Word for "G". Who Are the Heroes of the Queer Before Gay Time?). "Poznańskie Studia Slawistyczne" 16. Poznań 2019. Publishing House of the Poznań Society for the Advancement of the Arts and Sciences, Adam Mickiewicz University, pp. 193-208. ISSN 2084-3011.

Who (and what) was silent about the story told by heteronormative society? And how is the fragment of this story seen by "Others"? The article shows that the time of "queer before gay" includes (in Polish) not only well-known names such as: aunt or pedal, but also slang: 'lala' (doll), 'przyjaciółki' (friends), 'siostry' (sisters in Polish, girls in English), gays “from the outside of society", as well as heterosexuals who got a ticket to the alternative world of the excluded. I tell this story from the perspective of the performative function of language (Althusser, Austin, Butler) and mechanisms of knowledge/power (Foucault). I focus on the activities of homosexual men encoded in their "hiding language" (sociopolitan gay). I show how the creation of the "homosexual" identity closed the community of aunts and pedals in a precisely defined form. And how camp and queering reality allowed them to function in this form. This article is thus another element of decoding the so-called language of concealment, so-called sociolect of Polish gays (aunts and pedals) and queering history of Poland (part of the queering history of Central and Eastern Europe).

KeYwoRds: queer history; sociolect of Polish gays; camp; queer theory; lavender linguistics

W połowie lat 80 . XX wieku pochylono się nad planem wprowadzenia nieznanego dotąd społeczeństwu słowa. Słowo to - współcześnie rzecz ujmując - miało być podstawą rebrandingu ,pedalskich” społeczności, ich nowego wizerunku. Zaczątkiem nowej tożsamości. Kiedy więc ci, których na przełomie XIX i XX wieku nazwano (oznaczono, określono) „homoseksualistami”, zaczęli nazywać sami siebie (po swojemu) - oznaczało to w rzeczywistości konstruowanie własnych tożsamości, niezależnie od tej pierwotnie narzuconej. Homoseksualiści jako wykluczeni, chorzy - bo 
medycznie i prawnie zdefiniowani, wyszli z uszytej dla nich na wymiar (nie)normy. Skonstruowali siebie na nowo. Stali się gejami.

\section{Nominacja: naz(y)wanie a przez(y)wanie}

„«Homoseksualista» to bowiem pseudotożsamościowy termin użyty przez władzę przeciwko gejom ${ }^{1}$, termin przemocowy, wyjęty z dyskursu państwowej nauki, psychologii, seksuologii i mediów" (Szymański, 2018, 76). Konstrukcjoniści podkreślają, że do XIX wieku zachowania seksualne między osobami tej samej płci były - w zależności od czasu i kultury ignorowane, akceptowane bądź piętnowane, ale (co ważne) nie wpływały na definiowanie/różnicowanie ich uczestników. To znaczy, że wartościowaniu (i naz[y]waniu) podlegał akt seksualny per se, bez tworzenia nowych konstrukcji tożsamościowych. Zastanawiając się nad celem zaprojektowania nowej kategorii ludzi (czy, jak pisał Michael Foucault [2000, 45]: nowego gatunku), warto odnieść się do teorii interpelacji Althussera (Wróbel, 2012). Mianowicie dopiero nazwanie (i, w dalszej kolejności, zdefiniowanie) podmiotu pozwala na wybrane wobec tego podmiotu działania (choćby zmierzające do wykluczenia go z wybranej społeczności). Oczywiście pomijam w tej chwili to, że już sam akt nazwania podmiotu jest warunkiem jego ustanowienia w języku, powołania go do życia, uczynienia go - właśnie - podmiotem. Bartłomiej Lis, odpowiadając na pytanie: „Czy my w ogóle istniejemy?” stwierdza: „dopiero, gdy scharakteryzujemy określony typ, opiszemy, zdiagnozujemy, nazwiemy - możemy poddać go procedurom normalizującym - czyli wymazywania z przestrzeni społecznej jego inności. Tak zdefiniowanego pedała, łatwiej usunąć z pola, łatwiej przekreślić, czy unieważnić" (Lis, 2007).

Stworzony czy wprost: wymyślony nowy gatunek ludzi został, gombrowiczowsko rzecz ujmując: upupiony, tj. zamknięty w dokładnie określonej formie-(nie)normie, w stosunku do której - dopiero! - zdefiniowano (hetero)normę. Zbiorowo upupionym homoseksualistom, poddanym mechanizmom wiedzy/władzy, nadano jednorodną tożsamość: homoseksualistą

${ }^{1}$ Skreślenie autora (W. Szymańskiego). W ten sposób autor podkreśla, że w kontekście opisywanych wydarzeń nazwa „gej” jest anachronizmem. 
jest bowiem ten - jak podkreśla Judith Butler (2010, 124) - „kogo zawsze definiują inni, komu odmawia się prawa do określenia samego siebie w odniesieniu do seksualności”. Poprzez nazwanie, a w rzeczywistości: przezwanie $^{2}$, narzucamy podmiotowi tożsamość, wpisujemy go w porządek naszego świata. W efekcie osoba przezwana przestaje być soba, a zaczyna być kimś. Podmiotem, który możemy łatwo skategoryzować, określić, poddać binarnej ocenie: dobry lub zły, swój lub obcy - w myśl słów Bibliotekarza z Innego Miasta: „Sensowne i zrozumiałe jest dla nas tylko to, co porusza się po torach naszego świata" (Ajvaz, 2005, 174).

Judith Butler, analizując kreacyjną moc języka (opierając się m.in. na wspomnianej wyżej teorii interpelacji Althussera oraz performatywnych aktach mowy Austina), zwróciła uwagę na słynne już w teorii queer wyrażenia: „To chłopiec!”, „To dziewczynka!”, które, wypowiedziane w chwili narodzin dziecka, określając jego płeć, narzucają (projektują) rodzicom odpowiedni repertuar cech oraz społecznych i kulturowych oczekiwań wobec (płci) potomka. Sprowadzając te wyrażenia do formy: „Jesteś homoseksualistą!”, „Jesteście homoseksualistami!”, obarczono wybranych mężczyzn bagażem stereotypów i sztucznie ustalonych cech. Warto zaznaczyć, że jeszcze na przełomie XIX i XX wieku próbowano określić podstawowe (stałe) elementy każdego homoseksualnego mężczyzny, co prowadziło (z punktu widzenia współczesnej nauki) do kuriozalnych teorii, np. skupiających się na kształtach poszczególnych części ciała dewianta (A. Tardieu wskazywał na lejkowatą deformację odbytu [Tamagne, 2009, 168]) czy na temperaturze, która miała być wyższa od temperatury ciała przeciętnego heteroseksualnego mężczyzny (co zresztą znalazło swoje odzwierciedlenie w języku, w nazwach takich jak: ciepły, cieplak w Polsce, teplouš w Czechach, teplý brat i slangowy teploš na Słowacji oraz słoweński, wulgarny: toplovodar czy węgierski, neutralnie nacechowany i odpowiadający leksemowi ,gej” w innych językach: meleg (Nowak, 2017b, 251-252).

W tym miejscu dochodzimy do pytania postawionego w tytule: „Kim są bohaterowie czasów queer before gay?”. To znaczy czasów polskich

${ }^{2}$ „Chociaż pewne formy krzywdzącego języka polegają na użyciu określonych nazw przezwania kogoś jakimś imieniem, inne formy wydają się opierać na deskrypcjach, a nawet przemilczeniach" (Butler, 2010, 39). 
ciot i pedałów, czechosłowackich buzerantów i postsowieckich gołubojów, piedików i pietuchów. Czasów amerykańskich queerów i queenów. Interesuje mnie zatem to, kogo (i co) przemilczała (hetero)norma i jak ten fragment historii (ograniczony na potrzeby artykułu do lat 50.-90. XX wieku) opowiadany jest przez Innych spoza „tożsamościowego projektu «gay»". Wyrażam przy tym nadzieję, że tekst ten, będący kolejnym ${ }^{3}$ elementem dekodowania tzw. języka ukrycia, czyli socjolektu polskich gejów (ciot i pedałów ${ }^{4}$ ), odkryje również kolejne karty queerow(an)ej historii Polski ${ }^{5}$ (wpisującej się w szerszy projekt queerow[an]ej historii Europy Środkowo-Wschodniej).

\section{Chłopak jak ta lala}

„Działo się to w czasach, kiedy w naszym kraju panoszyła się komuna, młodzież wierzyła w lepsze jutro [...], a na bale karnawałowe zapraszano jedynie przodowników pracy" (MEN Magazyn, 1993, 6-7) - tak w czasopiśmie dla gejów wspomina swoją historię z lat 50. anonimowy mężczyzna, dodając: „Już wtedy wiedziałem, że jestem lalą”. Lale spotykali się m.in. w „Pajacu” - tak wówczas nazywano Pałac Kultury i Nauki, który po 1975 roku stał się częścią „Broadwayu” (v. Nowak, 2016, 177-178), czyli największej pedalskiej „,pikiety” (miejsca spotkań gejów) w Warszawie. Broadway ciągnął się od Dworca Centralnego, przez podziemia (w których znajdowała się m.in. „galeria”, czyli miejsce obserwacji „lujów” - heteroseksualnych mężczyzn), po toalety na siódmym i ósmym piętrze PKiN. W każdym razie istotną w tej historii jest „lala" - chciałoby się rzec: babka geja. Dziś „lala” jest już zupełnie zapomniana, choć trzeba podkreślić, że

${ }^{3}$ Obok artykułów: O zapisanym stownictwie mniejszości seksualnych (Dyszak, 2015), Gdzie jest gej? O (nazwach) przestrzeni w pierwszych polskich pismach gejowskich (Nowak, 2016) i O kulturowych relacjach między wybranymi nazwami geja (Nowak, 2017b).

${ }^{4}$ Leksemów ,ciota” i ,pedał” używam w artykule bez wulgarnego nacechowania, odnosząc się do ich (zwykle) neutralnego znaczenia w socjolekcie gejów (jako nazw członków określonej społeczności).

${ }^{5}$ Mam tu na myśli przede wszystkim artystyczną działalność Karola Radziszewskiego (przy współpracy z Ryszardem Kisielem), prace Krzysztofa Tomasika (2012; 2014) oraz m.in. badania Magdy Szcześniak (2012; 2016), Grzegorza Niziołka (2016) oraz Wojciecha Śmiei (2010). 
wówczas była bardzo funkcjonalna - kiedy w heteronormatywnym towarzystwie można było po prostu powiedzieć kilka słów o „swojej lali”, konotującej nieznającym ,języka ukrycia” żonę czy narzeczoną.

„Był lalą, choć nie dawał tego po sobie poznać” (MEN Magazyn, 1993, 6-7). Kamuflaż to słowo klucz tamtych czasów. Po otwarciu Dworca Centralnego, 5 grudnia 1975 roku, lale, cioty i każdy Inny (zainteresowany stosunkiem seksualnym z mężczyzną) rekodowali nową przestrzeń dworcowe toalety. Brak gay clubów (wynikający, literalnie rzecz ujmując, z braku gejów) i darkoroomów prowadził bowiem do subwersji przestrzeni publicznej i, w efekcie, tworzenia pedalskich heterotopii (Foucualut, 2005, Nowak, 2017a). Subwersja ta polega(ła) na symbolicznym przejęciu wybranego miejsca (baru, parku, łaźni, toalety itd.), odarciu go z heteroseksualnej tożsamości ${ }^{6}$ i wpisaniu w nowy homoseksualny kontekst. Tworzono w ten sposób miejsca o nowym znaczeniu, alternatywną rzeczywistość znaną tylko członkom ciotowskich społeczności. Dla niewtajemniczonych podróżnych dworcowa toaleta pozostawała więc dworcową toaletą, do której zmierzali za potrzebą, a dla - nomen omen - Innych była miejscem spotkań i przygodnego seksu. Dlatego też „wśród swoich” mówiło się np.: „Byłem w bibliotece głównej. Dużo nowych wydań. Poznałem dziewczynę z dużym warkoczem”. Na Centralny szło się bowiem w konkretnym celu - „pleść warkocze” 7 .

Zbigniew Libera w rozmowie z Karolem Radziszewskim podkreślał: „Oni musieli się bardziej ukrywać, musieli być tacy sami jak wszyscy. Nie wolno było się wychylić, bo za wychylenie zatrzymywał cię policjant, bo na przykład masz kolczyk w uchu, no przecież tak było" (Dik Fagazine, 2007, 66). Dlatego soba cioty mogły być dopiero po zmroku, na pikietach i na zamkniętych dla nieznajomych prywatkach. Trzeba też zaznaczyć, że $\mathrm{w}$ relacjach z policją (wtedy jeszcze z milicją) ukrywano nie tylko swoją homoseksualną orientację. „Było wiele morderstw, o których nie można było mówić i pisać w gazetach, choć milicja dobrze o nich wiedziała. Ale

${ }^{6}$ Bartłomiej Lis podkreśla, że przestrzeń publiczna jest zawsze naznaczona (hetero)seksualnie. Kiedy więc pojawia się w niej element homoseksualny - zwraca on uwagę przypadkowych przechodniów jako coś - dla nich - niecodziennego/nienaturalnego (Lis 2009).

${ }^{7}$ W socjolekcie gejów ,biblioteka główna” to Dworzec Centralny, ,pleść warkocze” uprawiać seks oralny, a „nowe wydania” - nowi chłopacy/mężczyźni, którzy pojawiali się na dworcowej pikiecie. 
odnotowywali je inaczej" (HomoWarszawa, 2009, 101). Wśród (wspomnianych już) lujów cioty wyróżniały więc „hieny”, które „poznawszy kogoś w Parku, lądują z nim w jego domu i... największym szczęściem dla gospodarza jest być tylko okradzionym" (Inaczej, 1995a, 41). Zapraszając zatem do swoich mieszkań poznanych na pikietach nieznajomych mężczyzn, nierzadko padało się ofiarą przestępstwa, które w mediach mogło zaistnieć co najwyżej jako: „tak zwane okoliczności”. „Zawieyski, ale też i Karol Hanusz, czy hrabia Henryk Rostworowski zginęli w tak zwanych okolicznościach" (Inaczej, 1995a, 41). Kradzieże (w porównaniu do zabójstw) tym bardziej były lekceważone, oznaczając tym samym lekceważący stosunek do samej ofiary - homoseksualnego mężczyzny:

Pamiętam z lat siedemdziesiątych taką sprawę gdy na komisariacie MO taki fakt kradzieży zgłosił gej, a milicjanci odpowiedzieli mu, że sam sobie winien, jak zaprasza do mieszkania nieznajomych facetów to niech teraz sam szuka winowajcy (Filo, 1988b, 6).

Zbyt znany homoseksualista i transwestyta zwany w Szczecinie „Władzią” został okradziony przez luja z telewizora. Gdy okradziony zgłosił kradzież u prokuratora tenże odmówił przyjęcia zgłoszenia o kradzieży argumentując, że sprawa od początku jest przegrana, gdyż strona przeciwna będzie się bronić wersją, że jest to ,prezent za sprawioną satysfakcję seksualną" (Filo, 1988c, 7).

Cioty dbając o swoje bezpieczeństwo - paradoksalnie - wolały przemilczeć kradzieże, niż stać się przedmiotem kpiny czy ujawnić swoją seksualną tożsamość, która mogłaby potem być podstawą ich prześladowań: „Gdyby milicja prowadziła takie sprawy dyskretnie, nie splamiła się szantażami czy rozpowiadaniem o naszych skłonnościach rodzinie, w pracy, sąsiadom, na uczelni itp. to i geje nie ukrywaliby takich przypadków" (Filo, 1988b, 6). Ostatecznie pozostawione same sobie społeczności ciot i pedałów musiały radzić sobie same. Za granicą wysportowani geje (i lesbijki) organizowali się w grupach „Pink Panters”, czyli homoseksualnych bojówkach, które strzegły bezpieczeństwa na pikietach, w Polsce co najwyżej wymierzano samosądy: „Zbyt znani geje gdyńscy «Chojniczanka» $\mathrm{i}$ «Rosa», gdy zostały oszukane przez luja pojechały za nim do Krakowa. Tam go odnalazłszy pobiły w celu zwrócenia przez niego ukradzionych walorów dewizowych" (Filo, 1988c, 7). 


\section{Cioty niejedno imię}

Leksem „ciota” (z)definiowany był już m.in. w pracach: J. Rodzoch-Malek (2012), A.S. Dyszaka (2012), T.Ł. Nowaka (2017b) oraz A. Rejtera (2013), więc w tym artykule ograniczę się do definicji i opisów „,cioty” z perspektywy socjolektu: leksem ten, zanim jeszcze pojawił się w polszczyźnie potocznej, funkcjonował już w socjolekcie gejowskim (,języku ukrycia”) i w gwarach więziennych. Polska „,iota” ma swoje odpowiedniki również za granicą: chorwacka tetka i macedońska tetkica, angielska aunt/auntie, francuska tata czy włoska zia (Nowak, 2017b; Dimoski, Kudzin, 2010).

Definicje leksemów „ciota” i „pedał” są płynne i niejednoznaczne (dlatego też w tym artykule zamiennie stosuję wyrażenia takie jak np. społeczności pedalskie, społeczności ciotowskie). W zależności od kontekstu wypowiedzi słowa te w socjolekcie nacechowane są neutralnie, kiedy nazywają wprost członków wybranej społeczności, lub - podobnie jak w polszczyźnie potocznej - funkcjonują jako negatywne, obraźliwe bądź wulgarne. Jest to o tyle ważne, że wśród ciot i pedałów (a współcześnie również w społeczności LGBTQ+) prowadzi to do podwójnego wykluczenia - po pierwsze przez heteronormatywne społeczeństwo, a po drugie przez osoby LGBTQ + . Na łamach pierwszych pedalskich zinów (a na początku lat 90. - również pierwszych gejowskich czasopism), zwłaszcza w listach do redakcji i w ogłoszeniach, pojawiały się nierzadko treści dzielące nieheteronormatywnych mężczyzn m.in. na - właśnie - „stereotypowe cioty", tzn. sfeminizowanych mężczyzn, odwiedzających nocą pikiety (parki, szalety) w poszukiwaniu przygodnego seksu, i na mężczyzn „spoza środowiska”: „nadawca liczy zapewne na to, iż jego odbiorca uczciwie sklasyfikuje siebie jako osobę "spoza środowiska», czyli uczciwego geja-prawiczka, lub «ze środowiska», czyli przegiętą, zniewieściałą ciotę, z której na ulicy śmieją się wszyscy przechodnie i w której towarzystwie zostaniemy natychmiast sklasyfikowani jako geje" (Inaczej, 2001, 8-11). Wyrażenie „spoza środowiska” podkreśla(ło) więc męskość podmiotu (w klasycznym znaczeniu „męskości”), wierność (przeciwstawianą ciotowskiej rozwiązłości) oraz jego „heterooptycznosć” (a wówczas: „lujoptyczność”), tzn. że osoba „spoza środowiska” nie różni się wyglądem i zachowaniem (przynajmniej na pierwszy rzut oka) od przeciętnego 
heteroseksualnego mężczyzny. Z czasem jednak słowa te stały się utartym, nagminnie powtarzającym się sloganem, pozbawionym pierwotnego znaczenia: „to określenie robiło, robi i prawdopodobnie będzie nadal robiło furorę w ogłoszeniach [...]. Dla jednych jest oczywistym wyrazem oczekiwań kierowanych wobec partnera, a dla innych szczytem hipokryzji i zakłamania" (Inaczej, 2001, 8-11).

\section{Twierdza szyfrów: język ukrycia i rytuały}

„Spoza środowiska” i ciotę różni tak naprawdę jedno: „przeginanie się”, czyli „udawanie kobiety [...] - wymachiwanie rękami, piszczenie, mówienie «ależ przestań» i «Boże Bożenka»" (Witkowski, 2014, 15), zachowując się przy tym jak ,poprzeginane gwiazdy, które zastałbyś w kawiarni, omdlewająco wsparte o bufety lub siedzące przy stolikach w nieprawdopodobnych pozach" (Inaczej, 1991, 8-9). Cioty, żyjąc w (s)tworzonych przez siebie heterotopiach: na pikietach, przy dworcowych szaletach, ale również $\mathrm{w}$ subwertowanych barach, na prywatkach i na premierach w operach i teatrach - stworzyły swój alternatywny świat. Przeginając rzeczywistość, odbierały to, co zabrało im heteronormatywne społeczeństwo: własną narrację. Podejmując więc grę z tożsamością, stworzyły swój styl i estetykę - kamp, język, kody i rytuały. Czesław Miłosz pisał:

dla mnie prowincjusza taki był Babilon, najnieznośniejszy przez poczucie, że przebywa się poza kręgiem wtajemniczonych w funkcjonowanie tej machiny i że rozumieją się oni wzajemnie na podstawie znaków i mrugnięć. [...] I te krawaty, garnitury, jedwabne skarpetki [...], wszystko to przedstawiało się egzotycznie i wrogo niby krąg kapłanów Baala (Miłosz, 1990, 222).

Zanim jeszcze Susan Sontag odebrała homoseksualistom kamp i przekazała go światu w formie estetyki przejaskrawienia, maskarady i celowej sztuczności, ten pierwotnie stanowił ,podstawowy kod [porozumienia], [...] styl lingwistyczny, system póz, [...] dekonstrukcyjny «tryb» odwracania standardowych binarności” (Perkovich, 2012, 48), dostępny wyłącznie członkom deprecjonowanej społeczności. Performatywna funkcja aktów mowy i spojrzenie na płeć jak na stylizację, a nie jak na cechę wrodzoną 
(Czapliński, 2012, 27) pozwoliły ciotom wymyślić siebie na nowo - nazwać i dookreślić - jak pisałem na wstępie: po swojemu. „«Ciotka» nie oznacza gorszego geja, oznacza jedynie jego sposób na życie" (Filo, 1990, 18). Stąd w socjolekcie ciot częste deminutiva, przerysowany, charakterystyczny wysoki ton oraz mówienie o sobie w rodzaju żeńskim i zwracanie się do siebie per „siostro”, „koleżanko” lub z wykorzystaniem pseudonimu, zawsze oryginalnego i najczęściej też rodzaju żeńskiego (np. Ziuta od imienia Józek bądź Obuwniczanka od działalności zawodowej [właściciel sklepu obuwniczego]):

Koleżanki na dworcu w Warszawie podnieciły się parę razy, że jeszcze jedna z nas została ministrem. Popiszczały, poplotkowały, jak to mają w zwyczaju, ale żadnej nie przyszło do głowy, żeby z czyjegoś łóżka robić polityczną aferę (MEN Magazyn, 1990, 8).

Zdjęcie i informacja „Prawdopodobnie mieszkanie Pragi” nie pozostawiało wątpliwości, że chodzi o Mariannę, czyli Marka B. Milczący telefon w mieszkaniu Marianny tylko potwierdzał przerażające przeczucia (Filo, 1994, 7).

Pisząc o ciotach, głównych bohater(k)ach czasów queer before gay - trzeba podkreślić mnogość (a zarazem procesualność) rodzajów/typów ciot, które tworzone były najczęściej wewnątrz mniejszych (np. lokalnych) społeczności. I tak wyróżnić można np. ciotki skrytki, czyli te, które nie obnosiły się ze swoją tożsamością, przez co przeginały się „,po ciuchu” lub wcale: „Osoba nader towarzyska, unikająca także rozgłosu i skandalu. Dbająca o własną reputację. Unika kontaktów środowiskowych" (Inaczej, 1995b, 64.), ciotki-pszczółki, odpowiedzialne za otwory służące do podglądania mężczyzn w toalecie: „Mimo wielokrotnego zabijania, zaklejania i wszelkiego rodzaju łatania tych ubytków, nawet blachą, ciotki-pszczółki jakoś przecierały szlak i po pewnym czasie telewizornia była znowu czynna” (Inaczej, 1994, 36) ${ }^{8}$ oraz ciotki-zasiłówki: „Wreszcie w swoim żywiole są wiecznie bezrobotne ciotki-zasiłówki, które potrafią pić wyłącznie na cudzy koszt" (Okay, 1991, 28). Jak wspomniałem - typy ciot wyodrębniano nierzadko z potrzeby chwili/sytuacji (podobnie zresztą jak ciotowskie pseudonimy), dlatego $\mathrm{w}$ tym tekście jedynie zaznaczam tę kwestię

${ }^{8}$ „Telewizornią” nazywano te kabiny w toalecie publicznej, między którymi (w ściance działowej) zrobiono otwór, by móc przez niego podglądać mężczyzn w kabinie sąsiedniej. Cioty, które robiły otwory, nazywano m.in. ciotkami-pszczółkami. 
jako istotny element queerow(an)ej historii, natomiast obu tym tematom ze względu na liczbę przykładów i różne motywacje, a także sposoby tworzenia rodzajów/typów oraz pseudonimów należałoby poświęcić osobną publikację.

Kolejnym elementem ukrytej rzeczywistości są kody i rytuały, dzięki którym na pikietach łatwiej można się rozpoznawać. Idąc do parku, należało więc zabrać ze sobą zapalniczkę bądź zapałki:

Zadając bowiem najprostsze pytanie: „Masz ogień?”, niezależnie od tego, czy się ognia naprawdę potrzebowało albo czy w ogóle się paliło - pytanie to pozwalało rozpoznać „swoich”, stawało się wstępem do rozmowy, która z kolei zakończona pytaniem: „Pójdziemy?”, mogła jednocześnie zakończyć się w krzakach (Nowak, 2017a, 57-58).

Również i te kody, i rytuały były zróżnicowane lokalnie. Autorzy HomoWarszawy. Przewodnika kulturalno-historycznego (2009) przytoczyli słowa Jerzego Gizy, który w 1963 roku pisał: „W jednym ze środowisk wielkomiejskich jest zwyczaj spacerowania w okresie letnim z czerwonym kwiatem w butonierce, w innym noszenie przy sobie i dzwonienie dużą wiązką kluczy, a jeszcze w innym ciche gwizdanie popularnej melodii" (HomoWarszawa, 2009, 94). Z kolei w operze czy teatrze podczas przerw w sztuce odbywały się ,pparady”. Ciotki paradowały wokół przybyłych gości, tzn. prezentowały się, przechadzając się korytarzem, oczywiście odpowiednim krokiem: „Kiedy studiowałem w Warszawie w latach 1981-87 poznałem ścieżkę operową. W holu głównym Teatru Wielkiego podczas przerw, w szczególności na premierach, spacerowali geje i można było się wypatrzyć wzajemnie. W ogóle zawsze geje bardziej interesowali się operą" (Jedliński, 2008).

Szczególne zainteresowanie sztuką (jak i podróżami koleją, o czym za chwilę), wykorzystywano w szyfrowaniu wiadomości. Jeszcze zanim pojawiły się pierwsze pedalskie ziny (w połowie lat 80 . XX wieku) i czasopisma (już w latach 90.), ogłoszenia towarzyskie umieszczano m.in. na ścianach toalet oraz w prasie głównego nurtu. Oczywiście tytuły gazet, w których można było znaleźć odpowiednio zakodowane informacje były W społeczności dobrze znane. W ten sposób do grona „koleżanek”, „sióstr” i „lal” - w mediach mainstreamowych dołączyli m.in. „przyjaciele” oraz „miłośnicy baletu”: „Co prawda w latach siedemdziesiątych, za Gierka, niektórzy geje też dawali swoje ogłoszenia, ale w bardziej zakamuflowanej 
formie, typu: «Miłośnik baletu, pozna również miłośnika baletu»” (Różowy PULS, 1994, 6). Z kolei „kabinalia”, czyli ogłoszenia towarzyskie lub - rzadziej - krótkie opisy aktów seksualnych, wypisywano na ścianach kabin w szaletach, na pikietach: ,Jeśli już wchodziłem do kabin, to ze względu na napisy na ścianach, które często były drobiazgowymi opisami męskiego seksu. [...] To był erzac pikantniejszej prasy gejowskiej, która miała się dopiero pojawić" (Inaczej, 1997, 31).

\section{Pociąg z pedałami versus pociąg do pedałów}

Powtarzalną cechą wielu gejów (i podobno również lesbijek) jest zamiłowanie do transportu szynowego. „To co łączy PRL-owskich i TITO-wskich homoseksualistów to czynnik pewnej bezdomności. I jedni i drudzy, w tym swoim bezkrólewiu, snują opowieści o minionych czasach, o wagonowych turnusach wczasowych, o dzikich plażach, o marszach młodości" (Dimoski, 2012, 41). W jednym z wywiadów opublikowanych w nr 8 ,Dik Fagazine” Paweł Kubara pyta Piotra Gladosa (który opowiadał o swoich seksualnych przygodach z nieznajomymi podczas pociągowych podróży), czy wspominani mężczyźni byli homo- czy heteroseksualistami. Jego rozmówca odpowiada: „Słuchaj, nie było nawet gadania” (Dik Fagazine, 2011, 85).

$\mathrm{Z}$ tej wypowiedzi wynikają (co najmniej) dwie istotne dla naszych rozważań rzeczy. Po pierwsze: społeczność gejów nie ograniczała się jedynie do homoseksualnych mężczyzn. Wracając do przytaczanych wyżej badań Judith Butler - definicja homoseksualności zawęża i/lub ogranicza jednostkę w swojej seksualnej tożsamości. Tymczasem widzimy, że na pikietach cioty polowały na lujów - heteroseksualnych mężczyzn. I ci heteroseksualni mężczyźni, jeśli nawet szli z nimi do ich mieszkań celem rabunku, wcześniej poddawali się umówionym stosunkom seksualnym, a samo zachowanie seksualne nie definiowało ich od razu jako „homoseksualistów”. Na „salonach” (mieszczących się w prywatnych mieszkaniach, funkcjonujących na zasadzie zamkniętej pikiety), które organizowane były zwykle przez artystów i na które wstęp mieli tylko wybrani i zaproszeni, pojawiali się również oficjalnie zdeklarowani heteroseksualni mężczyźni: „Homoseksualna arystokracja organizuje przeróżne orgietki, wspólne 
wczasy. Ma na swoim utrzymaniu pikolaków, żuli, gojków" (HomoWarszawa, 2009, 96). „Żul” z kolei nazywał wówczas młodego, zwykle niepracującego chłopaka, który - co ważne - modnie się ubierał i chętnie przyjmował prezenty oraz tzw. kieszonkowe od innych mężczyzn, oczywiście w zamian za seks. Miał jednak jedną wadę: drobne (a z czasem bardziej wyrachowane) przestępstwa, co czyniło z niego jednocześnie postrach, ale i źródło przyjemności ciotek-pikieciarek. Notabene, współcześnie osoby deklarujące się jako heteroseksualne, należące do społeczności LGBTQ+, nazywane są m.in. „heterogejami” (Cardon, 2012, 637).

Docieramy w ten sposób do drugiej kwestii wynikającej z opowieści Piotra Gladosa, a o której w niepublikowanym do 2011 roku wywiadzie mówił Michael Foucault: należy zadać pytanie, czym w zasadzie jest pojęcie seksualności? I czy nie powinniśmy wyzwolić się spod pojęcia seksualności na rzecz praw przyjemności? (Szcześniak, 2012, 213). Społeczności ciot i pedałów czasów queer before gay najwyraźniej realizowały się poza sztywnymi granicami narzuconej homoseksualnej tożsamości, wymykając się jej na rzecz przyjemności właśnie. Przy czym pisząc o ,społeczności ciot i pedałów”, z pełną świadomością piszę o społecznościach, w których obok osób homoseksualnych były również heteroseksualiści i Inni - być może wówczas niezdefiniowani/niedookreśleni (a dziś określani jako: LGBTIQA, LGBTQ+ itd.). Stąd celowo też pytam o bohaterów queer before gay, bohaterów przemilczanych i nazwanych/przezwanych (jedynie!) z zewnątrz.

\section{Queer before (and after) gay}

Magda Szcześniak zatytułowała drugą część swojej książki: Geje versus pedały. Paradoksy widzialności (Szcześniak, 2016, 158-277). Omawia w niej m.in. dyskusje publikowane w pedalskich zinach i czasopismach przełomu lat 80. i 90. XX wieku, kiedy cioty i pedały zastanawiali się nad - współcześnie rzecz ujmując - rebrandingiem społeczności, nowym wizerunkiem homoseksualności. Głównym problemem okazało się zdefiniowanie „,pedała” i „geja”, bowiem „,ciota” już na wstępie oddelegowana została by desygnować tych nierozerwalnie związanych z estetyką kampu (mówiąc wprost: zmanierowane przegięte cioty). Wraz z możliwością wprowadzenia internacjonalizmu: ,gay”, podkreślano np.: 
Mamy tę szansę, że wprowadzamy nowe słowo, które jest ogółowi nieznane i mamy możliwość obudowania go pozytywnym znaczeniem. Można nawet postarać się o definiowanie geja jako świadomego pedała, który chce walczyć o swoje prawa i szerzyć aktywnie tolerancję (Filo, 1988a. 12).

Z drugiej strony podawano przykład subwertowanego w Niemczech der Schwule - zastanawiając się, czy i w Polsce nie lepiej byłoby subwertować zakorzenionego już w języku polskim ,pedała” (zamiast wprowadzać obco brzmiące słowo z zagranicy). Bez względu na wybór ostatecznej nazwy ważne są jednak tutaj działania (i świadomość) pedalskich społeczności, które zmierzały do zaprojektowania niezależnej, jednostkowej tożsamości, wymykającej się narzuconemu, jednorodnemu podmiotowi zbiorowemu: „homoseksualiści”. Akt nazwania siebie gejem (a więc deklaracja pierwszoosobowa!) nie oznacza zatem przywdziania garnituru z góry określonych cech dystynktywnych - seksualność jest tutaj bowiem jedynie jednym $\mathrm{z}$ elementów składających się na pełną tożsamość człowieka. Ważne jest też - jak podkreśla Jacek Kochanowski w Fantazmacie zróżNICowanym - że gejem jest tylko ten, kto się za niego uważa. Kochanowski apeluje, by gejem nie być, ale wciąż się nim stawać, jak w spektaklu granym bez końca (Kochanowski, 2004, 157-169).

John Boswell zaznaczał z kolei, że skoro geje wolą się określać leksemem „gej”, to trzymanie się medycznego terminu „homoseksualiści” zaprojektowanego i spopularyzowanego w kontekście patologii, ,jest tak samo nieuzasadnione, jak byłoby używanie nadal określenia „negro”, gdy przestało ono być do przyjęcia dla czarnoskórych", tym bardziej, że ,[s]łowo «homoseksualny» implicite sugeruje, że główna cecha wyróżniająca gejów i lesbijki to ich seksualność, [choć n]ie wydaje się, by był jakiś dowód na to, że geje i lesbijki są istotami seksualnymi w większym lub mniejszym stopniu niż inni” (Boswell, 2006, 55).

Projekt tożsamościowy ,gej” zaciera jednak wypracowane przez Innych i przemilczane przez (hetero)normę tożsamości. Grzegorz Niziołek zauważa zresztą, że ,[p]aradoks wszelkich społeczności homoseksualnych polega więc na tym, że muszą się one wciąż wymyślać na nowo" (Niziołek, 2016). Kwestia tzw. pamięci zbiorowej w tym przypadku się komplikuje, tym bardziej że świadomość przeszłości jest istotnym elementem budowania tożsamości tworzonej wewnątrz i na pograniczu społeczności Innych. Tymczasem współczesne społeczności gejowskie, wydaje się, nie 
zdają sobie sprawy, że są jedynie punktem w historii: queer before and after gay. I że linearnie rzecz ujmując: po bohaterach tej opowieści, tj. lalach, ciotach, pedałach, a w końcu również po gejach nadejdzie nowy queer, kształtujący się w odpowiedzi na nowe warunki ekonomiczne, polityczne, kulturowe $\mathrm{i}$ - przede wszystkim - społeczne.

\section{Literatura}

Ajvaz, M. (2005). Inne miasto. W: Morderstwo w hotelu Intercontinental. Powrót starego warana. Inne miasto. Przeł. L. Engelking. Sejny: Pogranicze, s. 159-333.

Boswell, J. (2006). Chrześcijaństwo, tolerancja spoteczna i homoseksualność. Geje i lesbijki w Europie Zachodniej od poczatku ery chrześcijańskiej do XIV wieku. Przeł. J. Krzyszpień. Kraków: Zakład Wydawniczy Nomos.

Butler, J. (2010). Walczace stowa. Przeł. A. Ostolski. Warszawa: Wydawnictwo Krytyki Politycznej.

Cardon, P. (2012). Recepta na Odmieńca albo maszyna do (de)konstrukcji tożsamości. W: Kamp. Antologia przekładów. Red. P. Czapliński, A. Mizerka. Kraków: Universitas, s. 622-639.

Czapliński, P. (2012). Kamp - gry antropologiczne. „Teksty Drugie” nr 5, s. 11-32.

Dimoski, Z., Kudzin, P. (2010). Krótki słownik wyrazów homoseksualnych w językach serbskim, chorwackim i macedońskim. „Rita Baum” nr 16, s. 35-37.

Dimoski, Z. (2012). Język i stylizacja w wybranych utworach homoerotycznych (Macedonia, Chorwacja, Polska). W: Tabu w oku szeroko otwartym. Red. N. Długosz (współpraca Z. Dimoskiego). Poznań: Rys, s. 37-43.

Dyszak, A.S. (2012). Nazwy mężczyzn homoseksualnych we współczesnym języku polskim. „Studia Językoznawcze” t. 11, s. 55-80.

Dyszak, A.S. (2015). O zapisanym słownictwie mniejszości seksualnych. „Etnolingwistyka" t. 27, s. 201-220.

Foucault, M. (2000). Historia seksualności. Przeł. B. Banasiak, K. Matuszewski. Warszawa: Czytelnik.

Foucault, M. (2005). Inne przestrzenie. Przeł. A. Rejniak-Majewska. „Teksty Drugie” nr 6, s. 117-125.

HomoWarszawa. Przewodnik kulturalno-historyczny. (2009). Red. Y. Kostrzewa, M. Minałto, M. Pietras, W. Szot, M. Teodorczyk, K. Tomasik, K. Zabłocki. Warszawa: Abiekt.pl.

Jedliński, M. (2008). Dwa osobne światy - homoseksualizm w PRL (2). „Replika” nr 13, s. 16-17.

Kochanowski, J. (2004). Fantazmat zróżNICowany. Socjologiczne studium przemian tożsamości gejów. Kraków: Universitas.

Lis, B. (2007). Czy „my” w ogóle istniejmy? Między negacją a celebracją różnicy. "Queer.pl”, http://queer.pl/artykul/186600/czy-my-w-ogole-istniejemy. 8.05.2018. 
Lis, B. (2009). Seksualne obywatelstwo i nieheteronormatywne doświadczanie przestrzeni. „Kultura Popularna” nr 2(24), s. 104-112.

Miłosz, C. (1990). Zaczynajac od moich ulic. Wrocław: Wydawnictwo Dolnośląskie.

Niziołek, G. (2016). Coming in. Przyczynek do badania historii homoseksualności. „Teksty Drugie” nr 6, s. 282-296.

Nowak, T.Ł. (2016). Gdzie jest gej? O (nazwach) przestrzeni w pierwszych polskich pismach gejowskich. „Dziennikarstwo i Media” t. 7, s. 173-185.

Nowak, T.Ł. (2017a). Między drzewami, między słowami - o parku inaczej. „Czas Kultury" nr 3, s. 54-58.

Nowak, T.Ł. (2017b). O kulturowych relacjach między wybranymi nazwami geja. „Etnolingwistyka" t. 29, s. 245-255.

Perkovich, M. (2012). Michaśki, kamp, pedały i literatura amerykańska. „Teksty Drugie" nr 5, s. 33-49.

Rejter, A. (2013). Płeć - język - kultura. Katowice: Wydawnictwo Uniwersytetu Śląskiego.

Rodzoch-Malek, J. (2012). W jaki sposób mówi się w polszczyźnie o homoseksualizmie i osobach homoseksualnych? Analiza leksyki na podstawie danych leksykograficznych i tekstowych. [Niepublikowana rozprawa doktorska]. Warszawa: Uniwersytet Warszawski.

Szcześniak, M. (2012). Queerowanie historii. „Teksty Drugie” nr 5, s. 205-223.

Szcześniak, M. (2016). Geje versus pedały. Paradoksy widzialności. W: Normy widzialności. Tożsamość w czasach transformacji. Warszawa: Fundacja Bęc Zmiana, s. $158-277$.

Szymański, W. (2018). Anioł historii Queer Archives Institute, pedalskie przeszłości i queerowa przyszłość, „Szum” nr 20, s. 70-84.

Śmieja, W. (2010). Przeciw konstrukcjonistom. Teoria queer i jej krytycy. „Przestrzenie Teorii" nr 13, s. 223-242.

Tamagne, F. (2009). Era homoseksualizmu, 1870-1940. W: Geje i lesbijki: życie i kultura. Red. R. Aldrich. Przeł. P. Nowakowski. Kraków: Universitas.

Tomasik, K. (2012). Gejerel. Mniejszości seksualne w PRL-u. Warszawa: Wydawnictwo Krytyki Politycznej.

Tomasik, K. (2014). Homobiografie. Warszawa: Wydawnictwo Krytyki Politycznej.

Witkowski, M. (2014). Lubiewo bez cenzury. Warszawa: Świat Ksiązki.

Wróbel, S. (2012). Efekt interpelacji. ,Teksty Drugie” nr 3, s. 22-33.

\section{Artykuły w gejowskich zinach i czasopismach}

„Dik Fagazine” 2007, nr 6. Rozmowa Karola Radziszewskiego ze Zbigniewem Libera, s. 66.

„Dik Fagazine” 2011, nr 8. Wywiad Karola Radziszewskiego i Pawła Kubary z Piotrem Gladosem, s. 85. 
„Filo” 1988a, nr 2(14). O stowie gej, s. 12.

„Filo" 1988b, nr 3(15). Nasz świat, s. 6.

„Filo" 1988c, nr 3(15). Kryminatki dyrdymatki, s. 7.

„Filo" 1990, nr 2(20). Krzyk, s. 18.

„Filo” 1994, nr 5(56). Śmierć w wigilię, s. 7.

„Inaczej” 1991, nr 17. Za mundurem, s. 8-9.

„Inaczej” 1994, nr 10(52). Starych pikiet czar, s. 36.

„Inaczej” 1995a, nr 3(57). Raz jeszcze stów kilka o parku, s. 41.

„Inaczej” 1995b, nr 9(63). Epitetem rzuć mily, a powiem ci, kim jesteś..., s. 64.

„Inaczej” 1997, nr 1(79). Zakazane piosenki, s. 31.

„Inaczej” 2001, nr 6(132). Ja ze środowiska, s. 8-11.

„MEN Magazyn” 1990, nr 5. Homoseks i polityka, s. 8.

„MEN Magazyn” 1993, nr 2. Dawnych wspomnień czar, s. 6-7.

„Okay” 1991, nr 7. Ciotki alkoholiczki i ciotki abstynentki, s. 28.

„Różowy PULS” 1994, nr 2. Pogaduchy z Iweta, s. 6. 